\title{
The Albuneidae (Crustacea, Anomura) of the Dampier Archipelago, Western Australia
}

\author{
Christopher B. Boyko \\ Division of Invertebrate Zoology, American Museum of Natural History, \\ Central Park West 79 th Street, New York, NY, 10024 U.S.A. \\ email: cboykowamnh.org
}

\begin{abstract}
The albuneid fauna of Western Australia is summarized with two species, Paralbunea dayriti (Serene and Umali, 1965) and Squillalbunea mariellae (Serene, 1973), being recorded as new to the Western Australian fauna south of $20 \mathrm{~S}$. Both of these species, as well as Albunea occulta Boyko, 2002, are recorded as new to the Dampier Archipelago, bringing the total number of albuneids known from this region to four. Western Australian distribution maps for the three taxa represented by new material are provided.
\end{abstract}

\section{INTRODUCTION}

Eleven species of albuneids have previously been reported from Western Australia: Austrolepidopa trigonops Efford and Haig, 1968, A. caledonia Boyko and Harvey, 1999, Leucolepidopa sunda Efford, 1969, Paralbunea dayriti (Serene and Umali, 1965), Squillalbunea mariellae (Serène, 1973), Stemonopa insignis Efford and Haig, 1968, Albunea speciosa Dana, 1852, A. elioti Benedict, 1903, A. groeningi Boyko, 2002, A. occulta Boyko, 2002, and A. thurstoni Henderson, 1893 (see Boyko, 2002). This represents an impressive $23 \%$ (11/47) of all recognized Recent albuneid taxa and includes several of the rarest albuneids (e.g., S. insignis and L. sunda). However, only four records of albuneids occurring in Western Australia south of $20^{\circ} \mathrm{S}$ were previously known: two records of $A$. speciosa

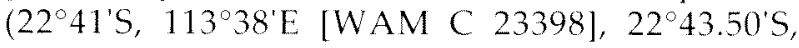
$113^{\circ} 39.50^{\prime} \mathrm{E}$ [WAM C 23399]), one record of $A$. occulta (20 54'S, $115^{\circ} 19^{\prime} \mathrm{E}$; WAM C 23392) (Boyko, 2002), and a single record of Albunea groeningi, from near Rosemary Island (WAM C 23386; Boyko, 2002). Albunea groeningi represents the only albuneid specimen reported from the Dampier Archipelago.

A small collection of albuneids obtained during the 1999 Dampier Archipelago Survey of the Western Australian Museum-Woodside Petroleum Partnership are reported herein, adding a further two species, $P$. dayriti and $S$, mariellae, to the Western Australian fauna south of $20^{\circ} \mathrm{S}$. Both these species, plus $A$. occulta, are new to the Dampier Archipelago fauna. The only albuneids that might be considered "common" (i.e., known from more than a very few records) in Western Australia are $P$. dayriti, A. groeningi and A. occulta.

It should be noted that the key given by Boyko (2002: 230) for species of Albunea is in error in that the thickness of the setae in couplet 16 was inadvertently reversed. The couplet should be written as follows:

16. Male telson with indented median ridge lined with thin setae 17

- Male telson with inflated median ridge lined with thick setae 20

\section{MATERIALS AND METHODS}

Abbreviations used in the text are as follows: $\mathrm{cl}$, carapace length as measured from the midpoint of the anterior margin (including rostrum, if any) to the midpoint of the posterior concavity; $\mathrm{mm}$, millimeters; n. mls, nautical miles; stn, station; WAM, Western Australian Museum, Perth.

\section{SYSTEMATICS}

Paralbunea Serène, 1977

Paralbunea dayriti (Serène and Umali, 1965)

Albunea dayriti Serène and Umali, 1965: 103.

Paralbunea dayriti. - Serène, 1979: 97.

\section{Material examined}

Western Australia, Dampier Archipelago. WAM C 26237 (1 male, d $5.9 \mathrm{~mm}$ ), stn DA2/99/24, $5.5 \mathrm{n}$. $\mathrm{mls} \mathrm{N}$ of Lady Nora I. $\left(20^{\circ} 21.79^{\prime} \mathrm{S}, 116^{\circ} 38.05^{\prime} \mathrm{E}\right.$ to $20^{\circ} 22.00 \mathrm{~S}, 11637.81^{\prime} \mathrm{E}$ ), rock and sand bottom, 38.5 $\mathrm{m}$, 17.07.1999; WAM C 26238 (1 male, cl $6.7 \mathrm{~mm}$ ), stn DA2/99/25, - $5.1 \mathrm{n} . \mathrm{mls} \mathrm{N}$ of Rosemary I. $\left(20^{\circ} 22.29^{\prime} \mathrm{S}, 116^{\circ} 35.56^{\prime} \mathrm{E}\right.$ to $\left.20^{\circ} 22.62^{\prime} \mathrm{S}, 116^{\circ} 35.44^{\prime} \mathrm{E}\right)$, muddy sand bottom, $39.0 \mathrm{~m}, 17.07 .1999$; WAM C 26242 (1 female, d $10.5 \mathrm{~mm}$ ), stn DA2/99/55, $3.2 \mathrm{n}$. $\mathrm{m} / \mathrm{s}$ NW of Roly Rock $\left(20^{\circ} 28.45^{\prime} \mathrm{S}, 116^{\circ} 27.43^{\prime} \mathrm{E}\right.$ to 


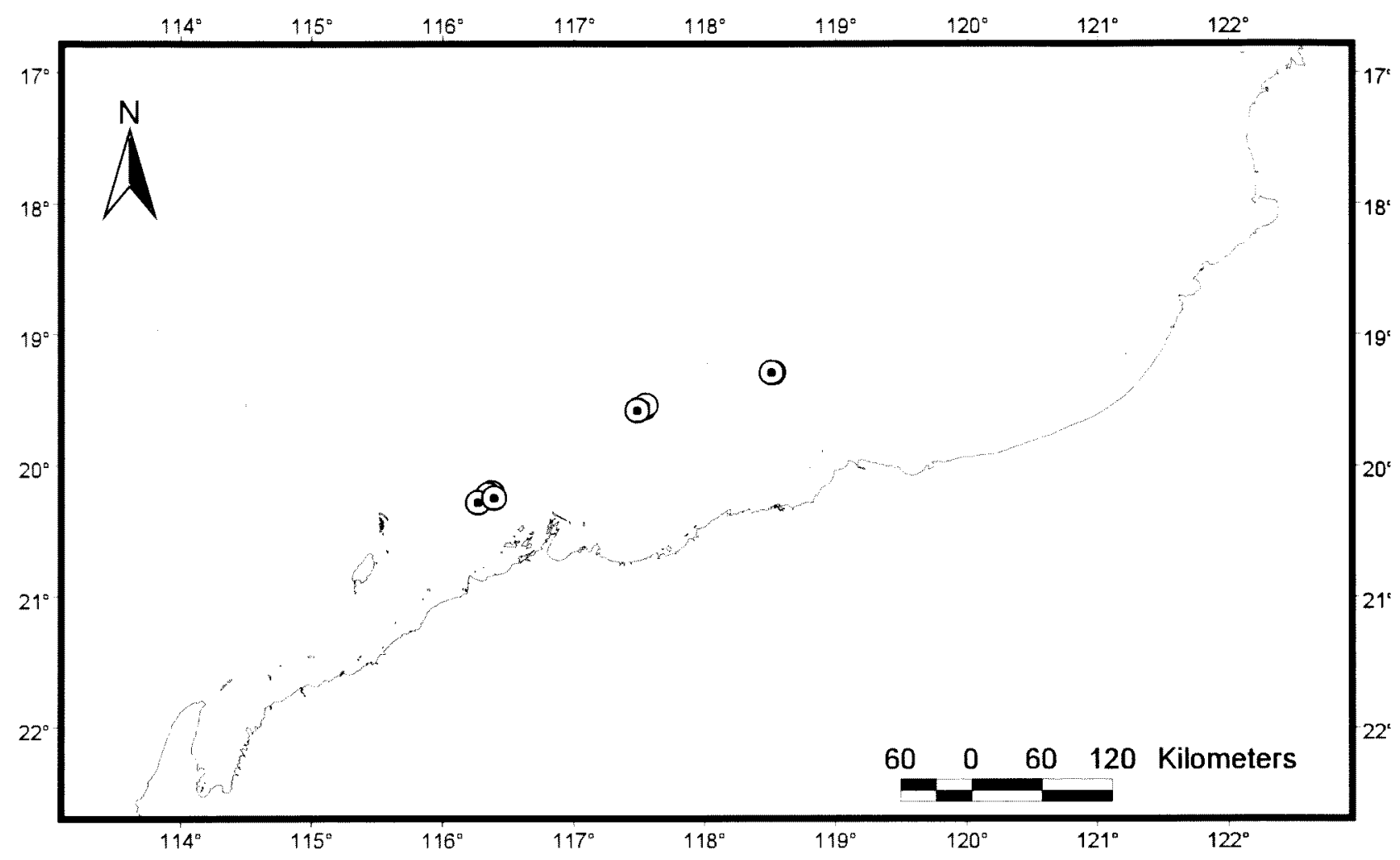

Figure 1 Distribution of Paralbunea dayriti (Serène and Umali, 1965) in Western Australia. Data from Boyko (2002) and herein.

$\left.20^{\circ} 27.98^{\prime} \mathrm{S}, 116^{\circ} 27.54^{\prime} \mathrm{E}\right)$, mud, sand and rocky rubble bottom, 37.5-38.0 $\mathrm{m}, 21.07 .1999$; WAM C 26246 (1 male, cl $8.6 \mathrm{~mm}$ ), stn DA2/99/87, $2.2 \mathrm{n}$. $\mathrm{mls} \mathrm{ENE}$ of $\mathrm{E}$ point of Brigadier I. $\left(20^{\circ} 25.48^{\prime} \mathrm{S}\right.$, $116^{\circ} 39.07^{\prime} \mathrm{E}$ to $20^{\circ} 25.23^{\prime} \mathrm{S}, 116^{\circ} 39.32^{\prime} \mathrm{E}$ ), fine sand bottom, $33.0-33.5 \mathrm{~m}, 26.07 .1999$.

\section{Bathymetric Range}

Within Dampier Archipelago, depth range 33.0$39.0 \mathrm{~m}$; over entire range, 6.1-45.5 m (Boyko, 2002).

\section{Distribution}

Southern Japan southward to Western Australia and eastward to New Caledonia, the Marshall Islands and Tahiti (Boyko, 2002).

\section{Squillalbunea Boyko, 2002}

\section{Squillalbunea mariellae (Serène, 1973)}

Albunea mariellae Serène, 1973: 261, pl. 1.

Squillalbunea mariellae. - Boyko, 2002: 215, figs 70, 71.

\section{Material examined}

Western Australia, Dampier Archipelago. WAM C 35466 [ex C 26237] (1 male, cl 5.9 m), stn DA2/99/ 24, $5.5 \mathrm{n}$. mls $\mathrm{N}$ of Lady Nora I. $\left(20^{\circ} 21.79^{\prime} \mathrm{S}\right.$, $116^{\circ} 38.05^{\prime} \mathrm{E}$ to $20^{\circ} 22.00^{\prime} \mathrm{S}, 116^{\circ} 37.81^{\prime} \mathrm{E}$ ), rock and sand bottom, $38.5 \mathrm{~m}, 17.07 .1999$; WAM C 26245 (1 unsexable, unmeasurable specimen [fragments]), stn DA2/99/58, $1 \mathrm{n}$. ml NNE of Roly Rock (20 29.11 'S, $116^{\circ} 30.78^{\prime} \mathrm{E}$ to $20^{\circ} 29.35^{\prime} \mathrm{S}, 116^{\circ} 30.55^{\prime} \mathrm{E}$ ), coarse shelly gravel and rock bottom, 25.0-25.5 m, 21.07.1999; WAM C 26247 (1 male, cl $6.1 \mathrm{~mm}$ ), stn DA2/99/89, $1.85 \mathrm{n}$. mls $\mathrm{N}$ of Gordon Pt, Rosemary I. $\left(20^{\circ} 27.33^{\prime} \mathrm{S}\right.$, $116^{\circ} 34.39^{\prime} \mathrm{E}$ to $20^{\circ} 27.17^{\prime} \mathrm{S}, 116^{\circ} 34.72^{\prime} \mathrm{E}$ ), coarse shell and rubble bottom, $27.0-28.0 \mathrm{~m}, 26.07 .1999$.

\section{Bathymetric Range}

Within Dampier Archipelago, depth range 25.0$38.5 \mathrm{~m}$; over entire range, to depth of $82.3 \mathrm{~m}$ (Boyko, 2002).

\section{Distribution}

Indonesia; Western Australia and Queensland, Australia; and the Marquises Islands (Boyko, 2002).

\section{Albunea Weber, 1795}

\section{Albunea occulta Boyko, 2002}

Albunea occultus Boyko, 2002: 313, figs 100, 101.

\section{Material examined}

Western Australia, Dampier Archipelago. WAM C 26240 (1 male, cl $12.6 \mathrm{~mm}$ ) stn DA2/99/42, $2.4 \mathrm{n}$. $\mathrm{mls}$ SW of SW point of Goodwyn I. $\left(20^{\circ} 34.16^{\prime} \mathrm{S}\right.$, $116^{\circ} 30.11^{\prime} \mathrm{E}$ to $20^{\circ} 33.67^{\prime} \mathrm{S}, 116^{\circ} 30.01^{\prime} \mathrm{E}$ ), rock and fine sand bottom, 14-16 m, 20.07.1999. 


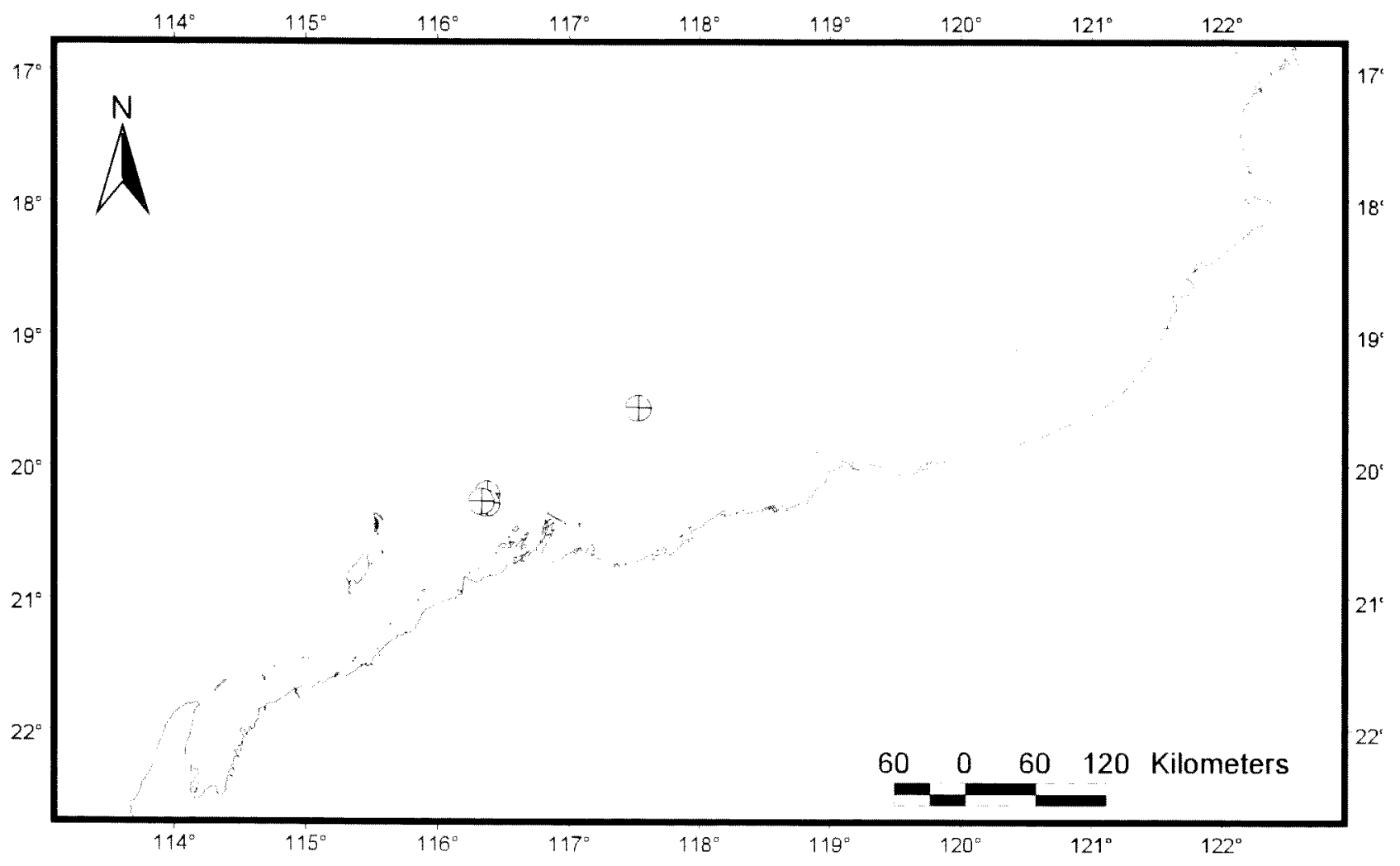

Figure 2 Distribution of Squillalbunea mariellae (Serène, 1973) in Western Australia. Data from Boyko (2002) and herein.

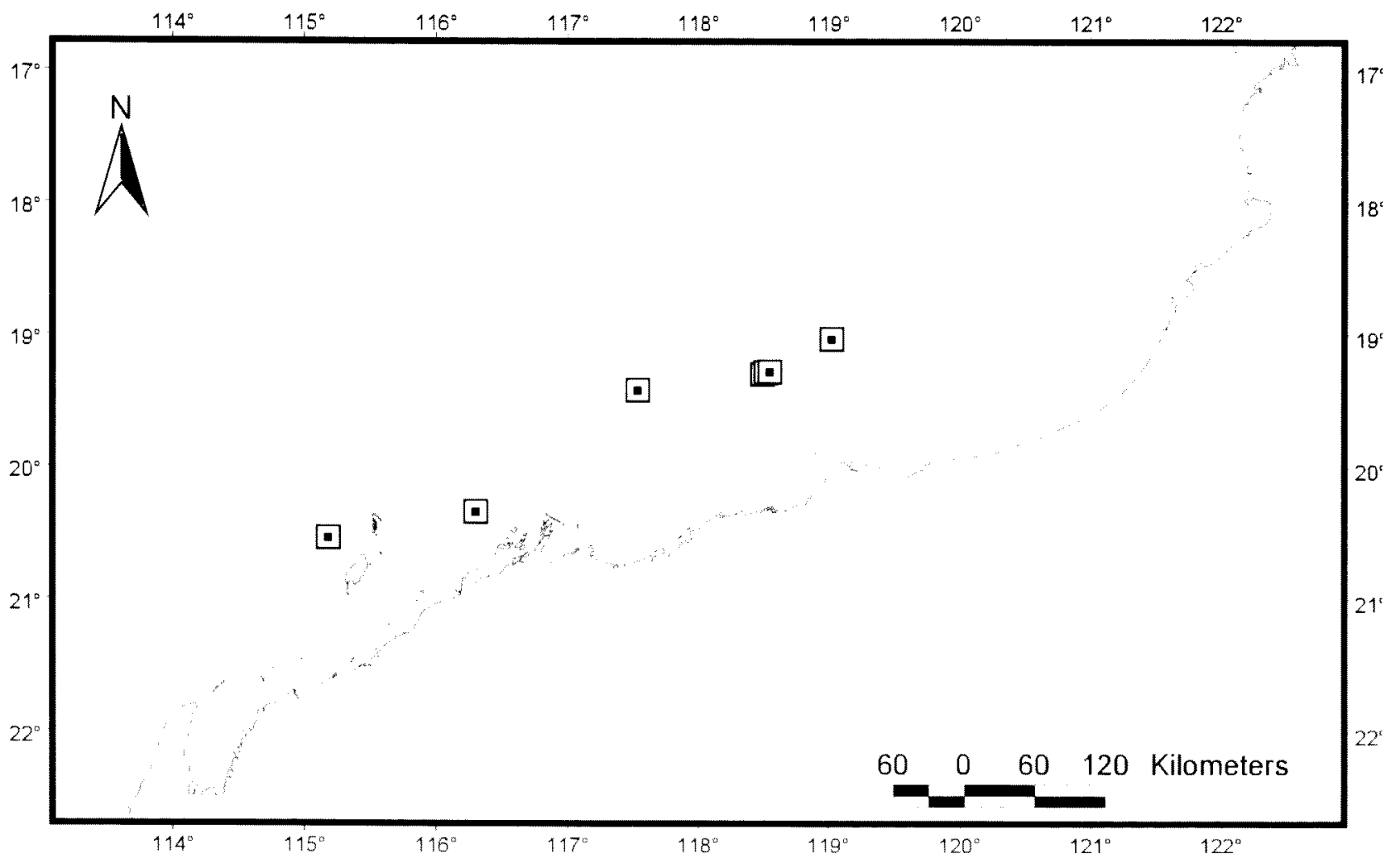

Figure 3 Distribution of Albunea occulta Boyko, 2002 in Western Australia. Data from Boyko (2002) and herein. 


\section{Remarks}

Although described as Albunea occultus by Boyko (2000), the ending of the species name must be changed from - us to - a to reflect agreement with the feminine genus name Albunea.

\section{Bathymetric Range}

Within Dampier Archipelago, depth range 14.0$16.0 \mathrm{~m}$; over entire range, in depths to $82 \mathrm{~m}$ (Boyko, 2002).

\section{Distribution}

Southern Japan southward to the eastern and western coasts of Australia (Boyko, 2002).

\section{CONCLUSIONS}

The specimens obtained from the Dampier Archipelago survey bring the total number of species known in this region to four but, given the typically low densities of albuneids in all regions of the world, it is possible that there may be more of the 11 known Western Australian species living in the Archipelago that remain unsampled.

Although the albuneid fauna of the Indo-West Pacific is now much better known than previously (Boyko, 2002), there are still many questions about these sand crabs that remain to be answered. We have a good understanding of the taxonomic richness of the family, but the distributions and depth ranges of individual species, to say nothing of the biological activities of albuneids in general, remain poorly known. Only through regional faunal studies, such as the Dampier Archipelago survey, can we hope to assemble a clearer picture of the distributional patterns of sand crabs throughout the Indo-Pacific, which will allow the eventual targeting of promising regional areas for the study of their biology and ecology.

\section{ACKNOWLEDGEMENTS}

I would like to thank Melissa Hewitt (WAM) for making this collection available for study. Reviews by Alan Harvey (Georgia Southern University) and an anonymous reviewer greatly improved the manuscript.

\section{REFERENCES}

Benedict, J.E. (1903). Revision of the Crustacea of the genus Lepidopa. Proceedings of the United States National Museum 26: 889-895.

Boyko, C.B. (2002). A worldwide revision of the Recent and fossil sand crabs of the Albuneidae Stimpson and Blepharipodidae, new family (Crustacea: Decapoda: Anomura: Hippoidea). Bulletin of the American Museum of Natural History 272: 1-396.

Dana, J.D. (1852). Crustacea. U.S. Exploring Expedition. During the years $1838,1839,1840,1841,1842$. Under the command of Charles Wilkes, U.S.N. Philadelphia: C. Sherman. 13: $685 \mathrm{pp}$.

Efford, I.E. (1969). Leucolepidopa sunda gen. nov., sp. nov. (Decapoda: Albuneidae), a new Indo-Pacific sand crab. Breviora 318: 9 pp.

Efford, I.E. and Haig, J. (1968). Two new genera and three new species of crabs (Decapoda: Anomura: Albuneidae) from Australia. Australian Journal of Zoology 16: 897-914.

Henderson, J.R. (1893). A contribution to Indian carcinology. Transactions of the Linnean Society of London, 2nd ser., 5: 325-458.

Serène, R. (1973). A new species of Decapoda Hippidea: Albunea mariellae nov. sp. from the Banda Sea. Crustaceana 24: 261-264.

Serène, R. (1977). Crustacés hippidés et brachyoures des îles Séchelles. Revue de Zoologie Africaine 91: 45-68.

Serène, R. and Umali, A.F. (1965). A review of Philippine Albuneidae, with descriptions of two new species. Philippine Journal of Science 94: 87-116.

Weber, F. (1795). Nomenclator entomologicus secundum entomologiam systematicam ill. Fabricii adjectis speciebus recens detectis et varietatibus. Chilonii et Hamburgi. viii +172 pp. 